Article

\title{
Effect of Climate Change on Service Life of High Volume Fly Ash Concrete Subjected to Carbonation-A Korean Case Study
}

\author{
Ki-Bong Park and Xiao-Yong Wang * \\ College of Engineering, Department of Architectural Engineering, Kangwon National University, \\ Chuncheon-Si 24341, Korea; kbpark@kangwon.ac.kr \\ * Correspondence: wxbrave@kangwon.ac.kr; Tel.: +82-33-250-6229 \\ Academic Editor: Yong Han Ahn \\ Received: 18 December 2016; Accepted: 18 January 2017; Published: 21 January 2017
}

\begin{abstract}
The increase in $\mathrm{CO}_{2}$ concentrations and global warming will increase the carbonation depth of concrete. Furthermore, temperature rise will increase the rate of corrosion of steel rebar after carbonation. On the other hand, compared with normal concrete, high volume fly ash (HVFA) concrete is more vulnerable to carbonation-induced corrosion. Carbonation durability design with climate change is crucial to the rational use of HVFA concrete. This study presents a probabilistic approach that predicts the service life of HVFA concrete structures subjected to carbonation-induced corrosion resulting from increasing $\mathrm{CO}_{2}$ concentrations and temperatures. First, in the corrosion initiation stage, a hydration-carbonation integration model is used to evaluate the contents of the carbonatable material, porosity, and carbonation depth of HVFA concrete. The Monte Carlo method is adopted to determine the probability of corrosion initiation. Second, in the corrosion propagation stage, an updated model is proposed to evaluate the rate of corrosion, degree of corrosion for cover cracking of concrete, and probability of corrosion cracking. Third, the whole service life is determined considering both corrosion initiation stage and corrosion propagation stage. The analysis results show that climate change creates a significant impact on the service life of durable concrete.
\end{abstract}

Keywords: high volume fly ash; concrete structures; carbonation; climate change; model

\section{Introduction}

To achieve sustainable development of the modern concrete industry, high volume fly ash (HVFA) concrete, which contains more than $50 \%$ fly ash in the binder, is widely used. The HVFA presents many advantages, such as improving the workability, minimizing the thermal cracking, and enhancing durability to sulfate attack and alkali-silica expansion [1,2]. However, HVFA concrete shows greater carbonation depth than normal concrete [1,2]. In particular, owing to an increase in $\mathrm{CO}_{2}$ concentrations and global warming, the rate of carbonation of concrete and rate of corrosion of steel rebars increases. Consequently, the service life of concrete structures decreases [1,2].

Numerous models have been proposed to evaluate the service life of concrete structures. Jiang et al. [3] proposed a mathematical model for the carbonation depth of HVFA concrete by considering mixing proportions, curing periods, and environmental conditions. Han et al. [4] evaluated carbonation depth and probability of corrosion initiation in harbor concrete structures. Taffese et al. [5] evaluated the carbonation depth by using machine learning methods that consisted of neural networks, decision trees, and ensemble methods. Marques et al. [6,7] proposed a carbonation service-life model considering the initial period and propagation period after carbonation. However, one element that has been missing in carbonation depth analysis and service life assessment of concrete in the 
aforementioned studies [4-7] is the effect of factors attributed to climate change, such as increases in the $\mathrm{CO}_{2}$ budget or changes in temperature.

With regard to the effect of climate change on the service life of concrete, Yoon et al. [8] proposed a model considering the effect of increase in $\mathrm{CO}_{2}$ concentration on the carbonation of concrete. The effects of water-to-cement ratio and exposure conditions on carbonation were considered. den Heede et al. $[9,10]$ proposed a model by considering the effect of global warming on the carbonation of HVFA concrete. However, Yoon et al. [8] and den Heede et al. $[9,10]$ did not consider the corrosion propagation period after carbonation. Talukdar et al. [11,12] proposed a carbonation model for concrete in different cities, such as Mumbai, London, New York City, Sydney, Toronto, and Vancouver. Furthermore, a service life model of concrete, considering corrosion initiation, propagation period, and climate change, has also been proposed [13]. Stewart et al. [14,15] evaluated the effect of climate change on the service life of concrete for chloride or carbonation-induced corrosion. The evolution of corrosion-induced damage was calculated. However, Talukdar et al. [11-13] and Stewart et al. [14,15] mainly focused on the service life of Portland cement concrete. The effect of mineral admixtures, such as HVFA, on service life was not considered. In addition, Talukdar et al. [11-13] and Stewart et al. [14,15] did not consider the non-uniform corrosion in concrete structures.

Summarily, because climate changes, corrosion propagation stage, and types of binders, are not taken into consideration by the current models, they cannot be used to evaluate the carbonation service life of HVFA concrete with climate change. To address the drawbacks in the current models [3-15], this study presents a probabilistic approach that predicts the service life of concrete structures subjected to carbonation-induced corrosion. The effects of concrete material properties, curing conditions, and climate change on service life are considered. The service life is determined considering the corrosion initiation stage and the corrosion propagation stage.

\section{Carbonation Service Life of HVFA Concrete}

\subsection{Corrosion Initiation Due to Carbonation}

Carbonation can be affected by both concrete properties and environmental conditions during the service life. The amount of carbonatable materials such as calcium hydroxide $(\mathrm{CH})$ and calcium silica hydrate (CSH) in concrete depends on the binder content in concrete mixing proportions and reaction degree of the binders. In our previous study [16], a blended-cement hydration model was proposed to simulate the kinetic hydration process of cement-fly ash blends. The volumetric phase fractions of hardening blended concrete are evaluated using reaction degrees of the binders. For cement-fly ash blends, the $\mathrm{CH}$ content can be determined as follows [16]:

$$
C H(t)=C_{0} \times C H_{C E} \times \alpha-P \times v_{F A} \times \alpha_{F A}
$$

where $C_{0}$ is the mass of cement, $\mathrm{CH}_{C E}$ is the mass of $\mathrm{CH}$ produced by the hydration of unit mass of the cement, $\alpha$ denotes the degree of hydration of cement $\left(C_{0} \times C_{C E} \times \alpha\right.$ considers the production of $\mathrm{CH}$ from cement hydration), $P$ is the mass of fly ash, $v_{F A}$ is the stoichiometric ratio of the masses of $\mathrm{CH}$ and fly ash $\left(v_{F A}=0.845-0.7 \times \frac{P}{P+C_{0}}[16]\right)$, and $\alpha_{F A}$ denotes the degree of reaction of fly ash $\left(P \times v_{F A} \times \alpha_{F A}\right.$ accounts for the consumption of calcium hydroxide from the fly ash reaction).

Both cement hydration and fly ash reaction will produce calcium silicate hydrate (CSH). The compound formula of $\mathrm{CSH}$ produced from cement hydration is $\mathrm{C}_{1.7} \mathrm{SH}_{4}$ [16]. $\mathrm{CSH}$ produced from fly ash reaction has a lower $\mathrm{Ca} / \mathrm{Si}$ ratio than that produced from cement hydration, and the compound formula of $\mathrm{CSH}$ produced from fly ash is $\mathrm{C}_{1.1} \mathrm{SH}_{3.9}$ [16] (Ca/Si ratio also depends on the type of fly ash; this point is not considered in this study). The $S$ in cement and fly ash will form CSH [17]. By using the binder contents, reaction degree of binders, and compound formula of $\mathrm{CSH}, \mathrm{CSH}$ contents can be calculated as follows:

$$
\operatorname{CSH}(t)=\mathrm{CSH}_{\mathrm{C}}(t)+\mathrm{CSH}_{F A}(t)
$$




$$
\begin{aligned}
\mathrm{CSH}_{C}(t) & =3.78 \times f_{S, C} \times C_{0} \times \alpha \\
\mathrm{CSH}_{F A}(t) & =3.19 \times f_{S, P} \times P \times \alpha_{F A}
\end{aligned}
$$

where $\mathrm{CSH}_{\mathrm{C}}$ and $\mathrm{CSH}_{\mathrm{FA}}$ denote the $\mathrm{CSH}$ produced from cement hydration and fly ash reaction, respectively, $f_{S, C}$ and $f_{S, P}$ are the weight fractions of $S$ in cement and fly ash respectively. The coefficient 3.78 in Equation (3) is the mass ratio between the molar weight of $\mathrm{C}_{1.7} \mathrm{SH}_{4}$ and the weight of oxide $\mathrm{SiO}_{2}$ in $\mathrm{C}_{1.7} \mathrm{SH}_{4}$. The coefficient 3.19 in Equation (4) is the mass ratio between the molar weight of $\mathrm{C}_{1.1} \mathrm{SH}_{3.9}$ and the weight of oxide $\mathrm{SiO}_{2}$ in $\mathrm{C}_{1.1} \mathrm{SH}_{3.9}$.

The porosity of the hydrating concrete is reduced owing to the hydration of Portland cement, reaction of fly ash, and the carbonation of concrete. The porosity can be estimated as follows $[17,18]$ :

$$
\varepsilon(t)=\frac{W}{\rho_{W}}-0.25 \times C_{0} \times \alpha-0.1 \times \alpha_{F A} \times P-\Delta \varepsilon_{C}
$$

where $\varepsilon$ is the porosity, $W$ is the water content, and $\rho_{W}$ is the density of water. $0.25 \times C_{0} \times \alpha$ denotes the porosity reduction from the hydration of cement, while $0.1 \times \alpha_{F A} \times P$ denotes the porosity reduction from the reaction of fly ash; $\Delta \varepsilon_{C}$ denotes the porosity reduction due to concrete carbonation.

Papadakis $[17,18]$ proposed that when relative humidity in the environment is higher than 0.55 , carbonation of concrete is controlled by the diffusion of $\mathrm{CO}_{2}$. The carbonation depth of concrete can be determined as follows:

$$
\begin{gathered}
x_{c}=\sqrt{\frac{2 D\left[\mathrm{CO}_{2}\right]_{0} t}{[\mathrm{CH}]+1.7[\mathrm{CSH}]_{\mathrm{C}}+1.1[\mathrm{CSH}]_{\mathrm{FA}}}} \\
D=A\left(\frac{\varepsilon}{\frac{\varepsilon}{\rho_{c}}+\frac{W_{0}}{\rho_{w}}}\right)^{a}\left(1-\frac{R H}{100}\right)^{2.2}
\end{gathered}
$$

where $x_{c}$ is the carbonation depth of concrete, $D$ is the $\mathrm{CO}_{2}$ diffusivity, $\left[\mathrm{CO}_{2}\right]_{0}$ is $\mathrm{CO}_{2}$ molar concentration at the concrete surface, $[\mathrm{CH}]$ is the molar concentration of calcium hydroxide, $[\mathrm{CSH}]_{\mathrm{C}}$ is the molar concentration of $\mathrm{CSH}$ produced from cement hydration, $[\mathrm{CSH}]_{F A}$ is the molar concentration of CSH produced from the fly ash reaction, $\rho_{c}$ is the density of cement, $A$ and $a$ are $\mathrm{CO}_{2}$ diffusivity parameters, and $\mathrm{RH}$ is the environmental relative humidity. $[\mathrm{CH}]+1.7[\mathrm{CSH}]_{\mathrm{C}}+1.1[\mathrm{CSH}]_{\mathrm{FA}}$ in the denominator of Equation (6) is the content of carbonatable material.

Owing to climate change, the $\mathrm{CO}_{2}$ concentration and environmental temperature increase, and consequently the rate of carbonation of concrete is accelerated. Equation (6) is only valid for an exposure environment with constant $\mathrm{CO}_{2}$ concentration and $\mathrm{CO}_{2}$ diffusivity. For time-dependent $\mathrm{CO}_{2}$ concentration and $\mathrm{CO}_{2}$ diffusivity, Equation (6) is not valid. In this study, to consider the time-dependent climate changes, Equation (6) is re-written by using the difference method as follows:

$$
\begin{gathered}
d x_{c}=C R \times \frac{1}{2 \sqrt{t}} d t \\
C R=\sqrt{\frac{2\left[\mathrm{CO}_{2}(t)\right] \times D(t)}{[\mathrm{CH}]+1.7[\mathrm{CSH}]_{\mathrm{C}}+1.1[\mathrm{CSH}]_{\mathrm{FA}}}}
\end{gathered}
$$

where $d x_{c}$ is the increase of carbonation depth in one time step and $C R$ is the carbonation rate parameter.

The Intergovernmental Panel on Climate Change (IPCC) developed the climate scenario IS92a to predict atmospheric $\mathrm{CO}_{2}$ concentration changes. IS92a has been regarded as one of the best models among the various scenarios of global-mean change. Based on climate scenario IS92a, Yoon et al. [8] proposed that the time-dependent $\mathrm{CO}_{2}$ concentration in the next 100 years could be calculated as follows:

$$
\left[\mathrm{CO}_{2}(t)\right]=12.61 \ln (t)-95.17
$$


Figure 1 shows the time-dependent $\mathrm{CO}_{2}$ concentration. This figure shows that in the next 100 years, $\mathrm{CO}_{2}$ concentration in the atmosphere will almost double.

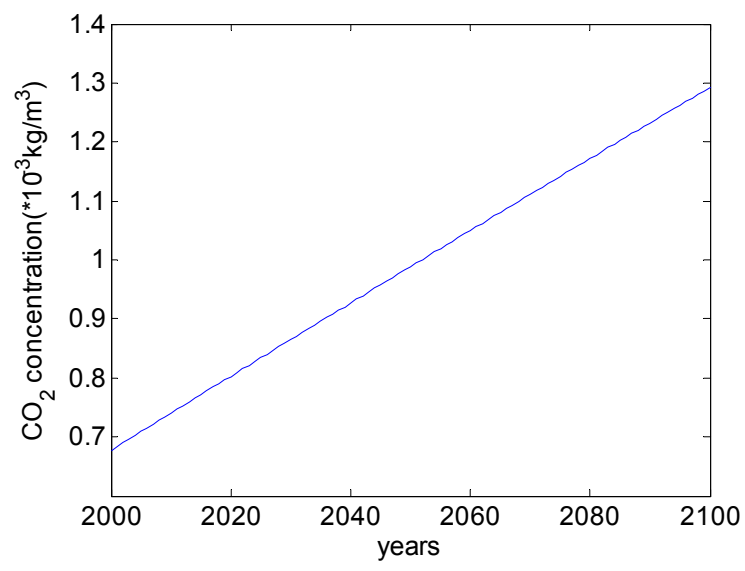

Figure 1. Increase in $\mathrm{CO}_{2}$ concentration [8].

The increase in the amount of $\mathrm{CO}_{2}$ is not the same as the increase that could happen in accelerated carbonation tests. Hence, the carbonation depth measured in accelerated carbonation tests is different from that in climate change conditions. Papadakis $[17,18]$ compared the carbonation of concrete under different $\mathrm{CO}_{2}$ concentrations, i.e., a natural environment $\left(0.03 \% \mathrm{CO}_{2}\right.$ by volume $)$ and an accelerated carbonation test (7\% and $50 \% \mathrm{CO}_{2}$ by volume). Papadakis $[17,18]$ found that Equation (6) is valid for concrete exposed to different $\mathrm{CO}_{2}$ concentrations, and the $\mathrm{CO}_{2}$ diffusivity parameters $A$ and $a$ of Equation (7) do not vary with $\mathrm{CO}_{2}$ concentrations $[17,18]$. Based on the accelerated carbonation results, the values of $\mathrm{CO}_{2}$ diffusivity parameters $A$ and $a$ can be set. Furthermore, by using $\mathrm{CO}_{2}$ concentration in the condition of climate change, the carbonation depth for the climate change condition can be determined (Equation (8)).

Based on meteorological data from Korea Meteorological Administration [19], it was observed that in the last 50 years the average temperature increased by about $1.1^{\circ} \mathrm{C}$. Hence, the increased temperature can be calculated as follows:

$$
\Delta T=\frac{1.1}{50} \times t
$$

where $\Delta T$ is the increased temperature. As shown in Figure 2, in the next 100 years, the environmental temperature will increase by about $2{ }^{\circ} \mathrm{C}$.

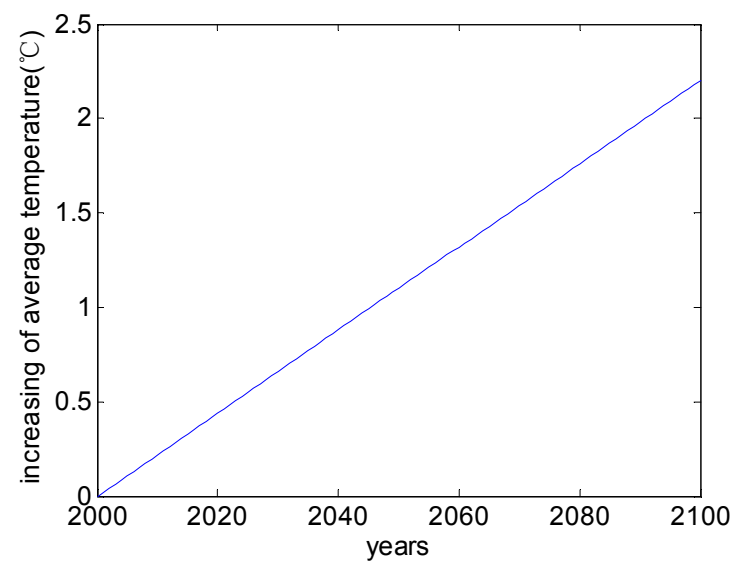

Figure 2. Increase in temperature. 
Papadakis et al. $[17,18]$ proposed that the dependence of $\mathrm{CO}_{2}$ diffusivity on temperature could be described using Arrhenius' Law as follows:

$$
D(T)=D_{r e f} \exp \left[\beta\left(\frac{1}{T_{r e f}}-\frac{1}{T}\right)\right]
$$

where $D_{r e f}$ is the $\mathrm{CO}_{2}$ diffusivity at reference temperature, and $\beta$ is the activity energy of $\mathrm{CO}_{2}(\beta=4300)$, $T_{r e f}(298 \mathrm{~K})$ is the reference temperature.

In the corrosion initiation stage, the durability failure criterion is defined as the carbonation depth exceeding the cover depth. Carbonation prediction involves uncertainties, such as physical uncertainty, statistical uncertainty, model uncertainty, and decision uncertainty [20]. Physical uncertainty is inherent in the random nature of basic variables such as concrete cover depth, environmental $\mathrm{CO}_{2}$ concentration, quality of concrete, and local conditions. Statistical uncertainty comes from the assumption for the probability density function. Model uncertainty is the governing mechanism for carbonation, such as a simplified equation of carbonation, assumption of material properties, and assumption of non-correlated variables. Decision uncertainty includes the definition of durability failure criteria, such as the period for which the carbonation depth exceeds cover depth. Considering the uncertainties in carbonation prediction, the durability failure probability can be determined by using the Monte Carlo simulation method as follows [20]:

$$
\begin{aligned}
& g(t)=C V-x_{C} \\
& p_{f}=\frac{n(g(t)<0)}{N}
\end{aligned}
$$

where $C V$ is the cover depth of concrete, $g(t)$ is the durability failure criterion, and $p_{f}$ is the probability of carbonation durability failure. $n(g(t)<0)$ denotes the number of instances of carbonation durability failure out of a total of $N$ trials.

The details about calculating the probability of corrosion initiation are as follows: 50,000 random samples for the parametric value were generated by the Monte Carlo simulation. The probability for carbonation to reach the depth of the steel rebar denotes the probability of corrosion initiation. This probability is calculated from the 50,000 random trials and is defined as the ratio of the number of instances of carbonation at the depth of the steel rebar, calculated by Equation (8), to the total number of trials $(50,000$ trials).

In the corrosion initiation stage, the time required to reach $10 \%$ failure probability was regarded as the service life of the concrete [20]. The service life can be determined for different levels of failure probability, based on the relation between the probability of corrosion initiation and time, by using the interpolation method.

\subsection{Corrosion Propagation after Carbonation}

After the carbonation depth of concrete exceeds the cover depth, corrosion of the steel rebar initiates. By using Faraday's law [21], the corroded depth of the steel rebar can be determined as follows:

$$
h=\frac{i_{s} \times t \times M_{F}}{2.5 \times F \times \rho_{F}}
$$

where $h$ is the corroded depth of the steel rebar, $i_{s}$ is the corrosion current density, $M_{F}$ is the atomic weight of iron corroded, $F$ is Faraday's constant, and $\rho_{F}$ is the density of iron.

An increase in temperature will increase corrosion current density. The relation between corrosion current density and temperature is as follows [14]:

$$
i_{s}(t)=i_{s-20} \times[1+k \times(T(t)-20)]
$$


where $i_{s-20}$ is the corrosion current density at $20^{\circ} \mathrm{C}$ (shown in Table 1), and $k=0.025$ if $T(t)<20^{\circ} \mathrm{C}$ and $k=0.073$ if $T(t)>20^{\circ} \mathrm{C}$ [14]. Owing to global warming, environmental temperature increases with time. To consider time-dependent temperatures, similar to those shown in Equations (8) and (9), the difference method is used.

Table 1. Carbonation corrosion rates $\left(i_{s-20}\right)$ for various exposures [14].

\begin{tabular}{lccc}
\hline \multicolumn{1}{c}{ Exposure Class } & Mean $\left(\mu \mathbf{A} / \mathbf{c m}^{2}\right)$ & Standard Deviation $\left(\mu \mathbf{A} / \mathbf{c m}^{2}\right)$ & Distribution \\
\hline C1 dry & 0 & 0 & \\
C2 wet-rarely dry & 0.345 & 0.259 & lognormal \\
C3 moderate humidity & 0.172 & 0.086 & lognormal \\
C4 cyclic wet dry & 0.431 & 0.259 & lognormal \\
\hline
\end{tabular}

The corroded depth of the steel rebar is not homogeneous. For carbonation-induced corrosion, corrosion generally occurs on the side of the steel rebar near the surface of the concrete. Using the corroded depth of the steel rebar, the degree of corrosion of the steel rebar can be determined as follows [21]:

$$
\eta=\frac{h}{R_{0}}
$$

where $\eta$ is the degree of corrosion of the steel rebar, and $R_{0}$ is radius of the steel rebar.

Once the degree of corrosion of the steel rebar exceeds a threshold value, the cracking of the surface concrete occurs. Wei et al. [21] performed a finite element analysis of the crack propagation process of concrete cover induced by non-uniform corrosion of the steel rebar. The analyzed threshold value of the degree of corrosion for cracking of the surface concrete is as follows [21]:

$$
\eta_{c r}=\frac{4 \delta_{0}+0.0624 \times f_{t}^{0.91}\left(1+\frac{C V}{2 * R_{0}}\right)^{1.98} \times\left(2 R_{0}\right)^{0.96}}{(\rho-1) \times\left(2 R_{0}\right)}
$$

where $\eta_{c r}$ is the threshold value of the degree of corrosion of the steel rebar for surface concrete cracking, $\delta_{0}$ is the thickness of the interfacial transition zone (ITZ) between the steel rebar and the concrete $\left(\delta_{0}=12.5 \mu \mathrm{m}\right)[21,22], f_{t}$ is the tensile strength of concrete, $\rho$ is the volumetric expansion ratio between corrosion products, and the original steel rebar $(\rho=2.17)[21,22]$.

In the corrosion propagation stage, the durability failure criterion is defined as the degree of corrosion exceeding the threshold value of the degree of corrosion for cracking of the surface concrete. The durability failure probability can be determined as follows [20]:

$$
g(t)=\eta-\eta_{c r}
$$

Similarly, by using the Monte Carlo simulation method [20], the probability of corrosion cracking and service life of concrete structures in the corrosion propagation stage can be determined.

\subsection{Summary of Carbonation Service Life Model}

The flow chart of carbonation service life is shown in Figure 3. Service life of concrete structures consists of two stages-the stage of corrosion initiation and stage of corrosion propagation.

\begin{tabular}{|l|l|l|l|}
$\begin{array}{l}\text { Input parameters: } \\
\text { Materials properties } \\
\begin{array}{l}\text { Curing conditions } \\
\text { Environmental conditions }\end{array}\end{array}$ & $\begin{array}{l}\text { Corrosion } \\
\text { initiation stage: } \\
d x_{c}=C R \frac{1}{2 \sqrt{t}} d t\end{array}$
\end{tabular}$\Rightarrow$\begin{tabular}{l}
$\begin{array}{l}\text { Corrosion } \\
\text { propagation stage: } \\
\eta=\frac{h}{R_{0}}\end{array}$ \\
$\begin{array}{l}\text { Sum of corrosion } \\
\text { initiation } \\
\text { propagation stages }\end{array}$ \\
\hline
\end{tabular}

Figure 3. Flowchart of model. 
With regard to the corrosion initiation stage, the input parameters are concrete mixing proportions, compound compositions of binders, curing periods, exposure to environmental conditions, and the cover depth. The climate change parameters such as increase in $\mathrm{CO}_{2}$ concentrations and environmental temperatures were considered through the carbonation prediction model. By using the probabilistic method, the service life of HVFA concrete in the corrosion initiation stage was determined.

With regard to the corrosion propagation stage, the input parameters are corrosion current density, cover depth, concrete tensile strength, and diameter of the steel rebar. The increase in corrosion current due to temperature increase was considered. Service life of concrete in the corrosion propagation stage was determined by using the Monte Carlo simulation method.

\section{Analysis Results of Carbonation Service Life of HVFA Concrete}

\subsection{Carbonation Depth in Accelerated Carbonation Tests}

Experimental results of the accelerated carbonation tests of HVFA concrete from Jiang et al. [3] were used to verify the proposed carbonation model. Jiang et al. [3] studied carbonation resistance of HVFA concrete with various mixing proportions and curing periods. Concrete specimens were first wet-cured for 28 days or 90 days at $20^{\circ} \mathrm{C}$. After the initial moist curing, accelerated carbonation tests of concrete were started. The accelerated carbonation tests were conducted in a test chamber with a temperature of $20^{\circ} \mathrm{C}$, a relative humidity of $70 \%$, and a $\mathrm{CO}_{2}$ concentration of $20 \%$. The carbonation depth was measured by using a phenolphthalein indicator.

By using the blended hydration model, the properties of HVFA concrete, such as $\mathrm{CH}$ content, $\mathrm{CSH}$ content, and porosity, were calculated. The results are shown in Figure 4. As shown in Figure 4a, for normal concrete, $\mathrm{CH}$ content continuously increases with curing age, while for HVFA concrete, in the initial stage, $\mathrm{CH}$ content increases. In this stage, the production of $\mathrm{CH}$ from cement hydration is dominant. After reaching a peak, the $\mathrm{CH}$ content begins to decrease because the pozzolanic reaction of fly ash becomes dominant. As shown in Figure 4b, the CSH content of HVFA concrete is much lower than that of normal concrete. As shown in Figure 4c, the porosity of HVFA concrete is higher than that of normal concrete. A lower CSH content and higher porosity will reduce the strength of the concrete. Hence, HVFA concrete generally has a lower compressive strength than normal concrete [3].

The calculation results from the hydration model, which included the $\mathrm{CH}$ content, $\mathrm{CSH}$ content, and porosity, were used as parameters for the carbonation model. In Jiang et al. [3], accelerated carbonation tests were conducted in a chamber with a $70 \%$ relative humidity. The relative humidity in the surface skin of concrete (carbonation reaction zone) approximately equals the environmental relative humidity. On the other hand, the rate of binder hydration is significantly influenced by relative humidity. When the relative humidity is less than $80 \%$, cement hydration virtually ceases [16]. Hence, further hydration in the carbonation zone of concrete is marginal and can be ignored.

By using the carbonation reaction Equation (6), the carbonation depth of concrete with different fly ash replacement ratios, different moist curing periods, and different water-to-binder ratios were calculated as shown in Figure $5\left(A=2.66 \times 10^{-6}\right.$ and $\left.a=2.75\right)$. As shown in Figure 5, with increase in the wet-curing periods, the carbonation depth of concrete decreases. This is because of the increase in the amount of hydration products and decrease in porosity. HVFA concrete shows a higher carbonation depth than reference concrete (shown from Figure 5a (reference concrete with no fly ash) to Figure $5 \mathrm{~b}$ (concrete with $55 \%$ fly ash replacement)). The carbonation depth of concrete decreases with decrease in the water-to-binder ratio, (shown from Figure $5 \mathrm{~b}$ (water-to-binder ratio 0.45 ) to Figure $5 c$ (water-to-binder ratio 0.38)). 


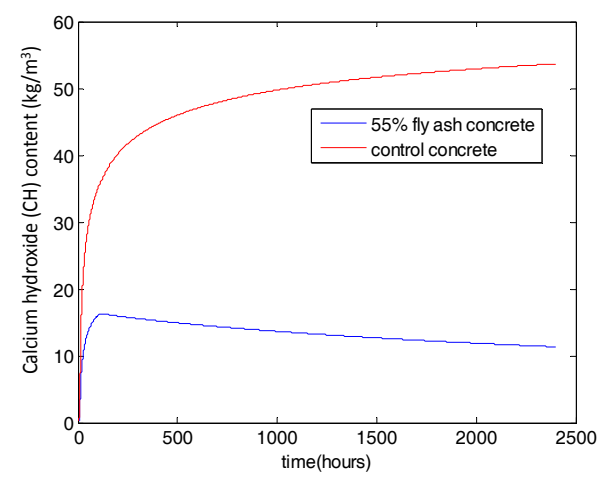

(a)

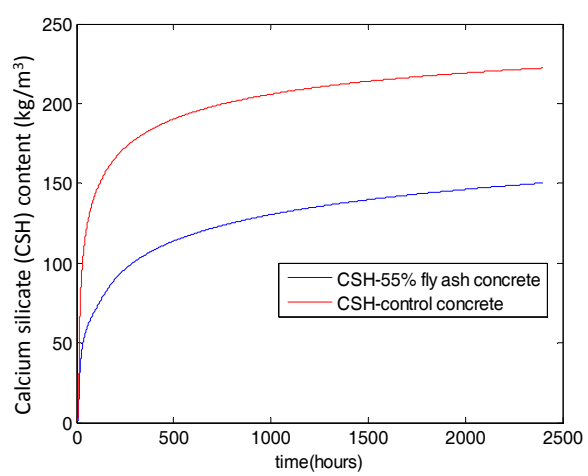

(b)

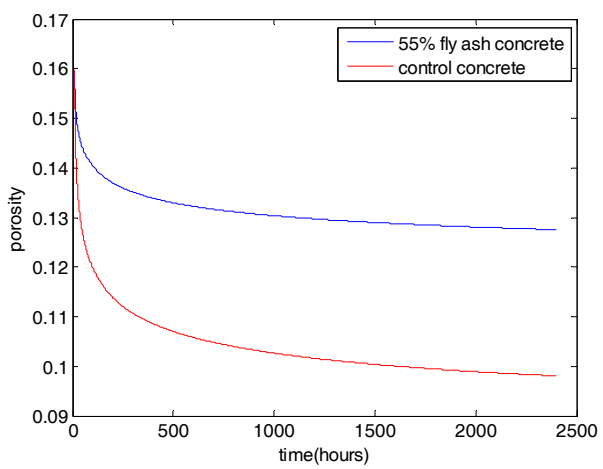

(c)

Figure 4. Evaluation of properties of HVFA concrete (water-to-binder ratio 0.5, fly ash replacement ratio 0.55 , binder content $330 \mathrm{~kg} / \mathrm{m}^{3}$ ). (a) CH content; (b) CSH content; (c) Porosity of concrete.

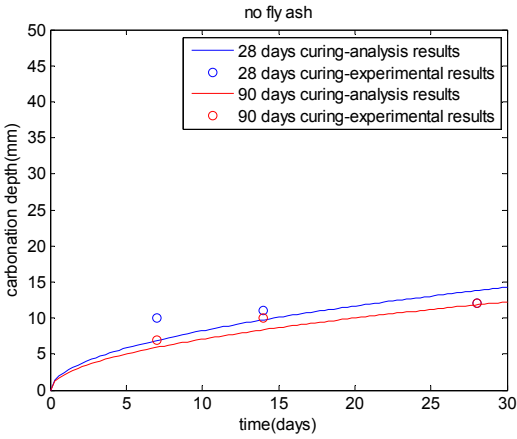

(a)

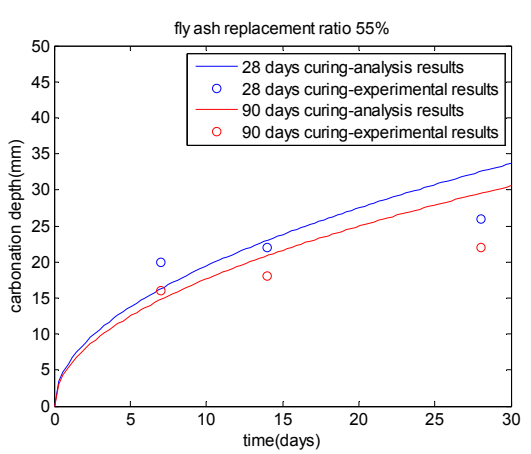

(b)

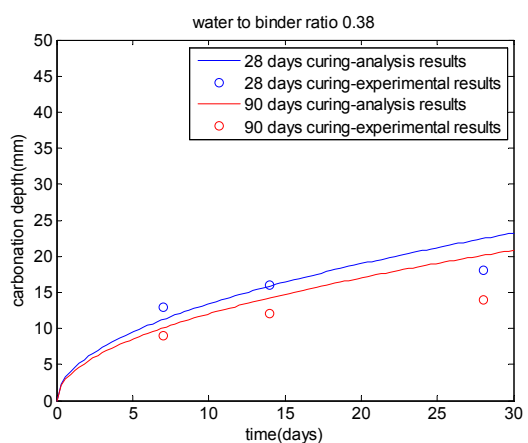

(c)

Figure 5. Carbonation depth of HVFA concrete. (a) Water-to-binder ratio 0.45 , no fly ash; (b) Water-to-binder ratio $0.45,55 \%$ fly ash; (c) Water-to-binder ratio $0.38,55 \%$ fly ash. 


\subsection{Service Life in the Corrosion Initiation Stage}

In the corrosion initiation stage, the service life of concrete is related to material properties, as well as environmental conditions. In this study, parameters were analyzed to consider the effects of concrete mixing proportions, initial wet-curing periods, and environmental conditions on the service life of HVFA concrete. Parameters for the carbonation model are shown in Table 2. Two different water-to-binder ratios ( 0.5 and 0.6$)$, two cover depths $(30 \mathrm{~mm}$ and $40 \mathrm{~mm})$, and two wet curing periods (seven days and 28 days) were used for parameter studies. Initial temperature was set to $20^{\circ} \mathrm{C}$, and initial $\mathrm{CO}_{2}$ concentration was set to $0.035 \%$. The increase in $\mathrm{CO}_{2}$ concentrations and environmental temperatures are considered by using Equations (10) and (11), respectively.

Table 2. List of parameters for carbonation model.

\begin{tabular}{|c|c|c|c|c|c|c|c|c|}
\hline \multicolumn{6}{|c|}{ Materials Properties } & \multicolumn{3}{|c|}{ Environmental Conditions } \\
\hline $\begin{array}{c}\text { Water-To- } \\
\text { Binder Ratios }\end{array}$ & $\begin{array}{c}\text { Concrete } \\
\text { Cover } \\
\text { Depth }\end{array}$ & $\begin{array}{l}\text { Moist } \\
\text { Curing } \\
\text { Periods }\end{array}$ & $\begin{array}{c}\text { Binder } \\
\text { Contents } \\
\left(\mathrm{kg} / \mathrm{m}^{3}\right)\end{array}$ & $\begin{array}{c}\text { Fly Ash } \\
\text { Replacement } \\
\text { Ratio }\end{array}$ & $\begin{array}{l}\text { Diameter of } \\
\text { Steel Rebar } \\
(\mathrm{mm})\end{array}$ & $\begin{array}{l}\text { Relative } \\
\text { Humidity }\end{array}$ & $\begin{array}{c}\text { Initial } \\
\text { Temperature } \\
\left({ }^{\circ} \mathrm{C}\right)\end{array}$ & $\begin{array}{c}\text { Initial } \mathrm{CO}_{2} \\
\text { Concentration } \\
(\%)\end{array}$ \\
\hline $0.5,0.6$ & $\begin{array}{l}30 \mathrm{~mm}, \\
40 \mathrm{~mm}\end{array}$ & $\begin{array}{l}7 \text { days, } \\
28 \text { days }\end{array}$ & 320 & 0.55 & 16 & 0.7 & 20 & 0.035 \\
\hline
\end{tabular}

In this study, the uncertainties in the concrete cover depth $(\mathrm{CV})$ and carbonation rate parameter $(C R)$ were considered. Statistical parameters for the carbonation model are summarized in Table 3. For $\mathrm{CO}_{2}$ concentration and environmental temperature, the coefficient of variation (COV) increases with time [14]. At the initial time, COV is zero and at the 100 year interval, COV is taken as 0.06.

Table 3. Statistical parameters.

\begin{tabular}{|c|c|c|c|}
\hline Parameter & Mean & Coefficient of Variance & Distribution \\
\hline \multirow{2}{*}{$\begin{array}{l}\text { concrete cover } \\
\text { depth }(C V)\end{array}$} & $30 \mathrm{~mm}$ & \multirow{2}{*}{$0.2[20]$} & \multirow{2}{*}{ Normal } \\
\hline & $40 \mathrm{~mm}$ & & \\
\hline $\begin{array}{c}\text { carbonation rate } \\
\text { parameter }(C R)\end{array}$ & $C R=\sqrt{\frac{2\left[\mathrm{CO}_{2}(t)\right] D(t)}{[\mathrm{CH}]+1.7[\mathrm{CSH}]_{\mathrm{C}}+1.1[\mathrm{CSH}]_{\mathrm{FA}}}}$ & $0.15[20]$ & Normal \\
\hline $\begin{array}{l}28 \text { days Compressive } \\
\text { strength }(\mathrm{MPa}) f_{c 28}\end{array}$ & $128 \exp \left(-2.63 \frac{W}{C_{0}+0.55 P}\right)[23]$ & $0.15[20]$ & normal \\
\hline $\begin{array}{l}28 \text { days tensile } \\
\text { strength }(\mathrm{MPa})\end{array}$ & $0.69 \sqrt{f_{c 28}}$ & $0.15[20]$ & normal \\
\hline $\begin{array}{l}\text { Rate of corrosion } \\
\qquad\left(\mu \mathrm{A} / \mathrm{cm}^{2}\right)\end{array}$ & 0.172 & $0.5[14]$ & lognormal \\
\hline $\mathrm{CO}_{2}$ concentration & {$\left[\mathrm{CO}_{2}(t)\right]$} & $\operatorname{COV}_{\max }(t)=0.06[14]$ & normal \\
\hline temperature & $\Delta T+20$ & $\operatorname{COV}_{\max }(t)=0.06[14]$ & normal \\
\hline
\end{tabular}

By using the carbonation model and Monte Carlo method, the probability of corrosion initiation can be calculated. As shown in Figure 6, climate change has a significant impact on the probability of corrosion initiation. With increase in the cover depth (comparisons between Figure $6 a, b)$, increasing curing periods (comparisons between Figure $6 \mathrm{a}, \mathrm{c}$ ), and decreasing water-to-binder ratios (comparisons between Figure $6 \mathrm{a}, \mathrm{d}$ ), the probability of corrosion initiation decreases, and consequently the service life of the concrete increases. 


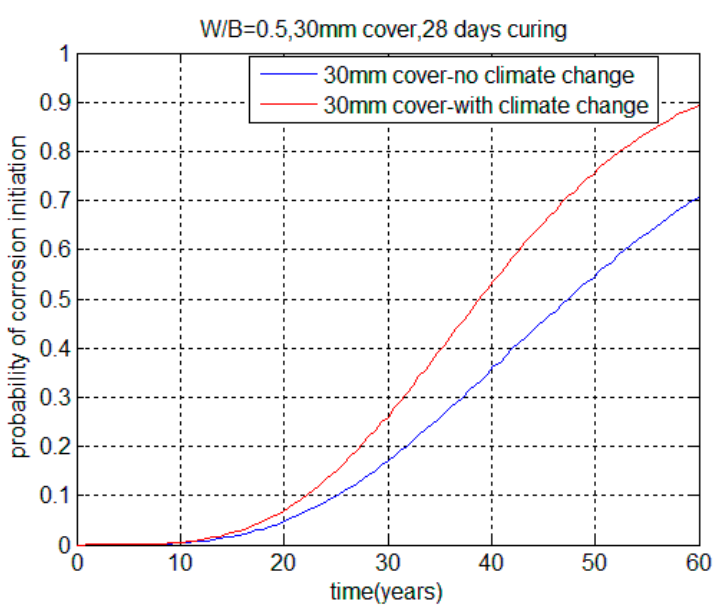

(a)

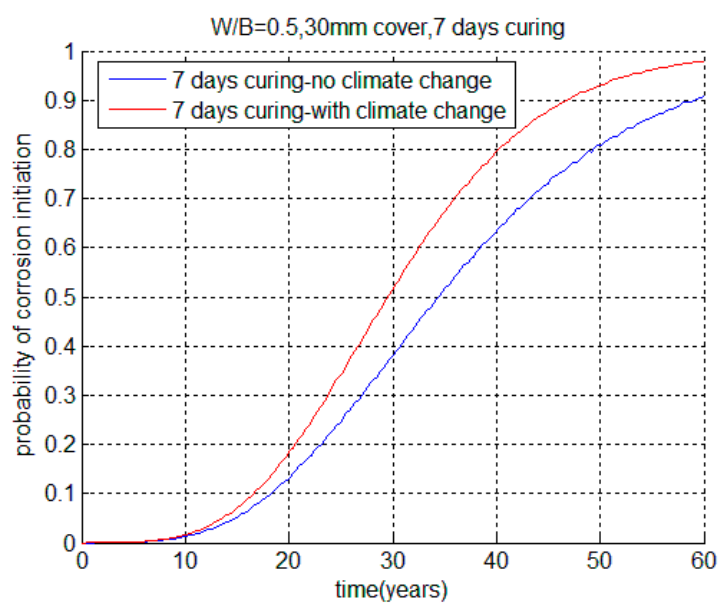

(c)

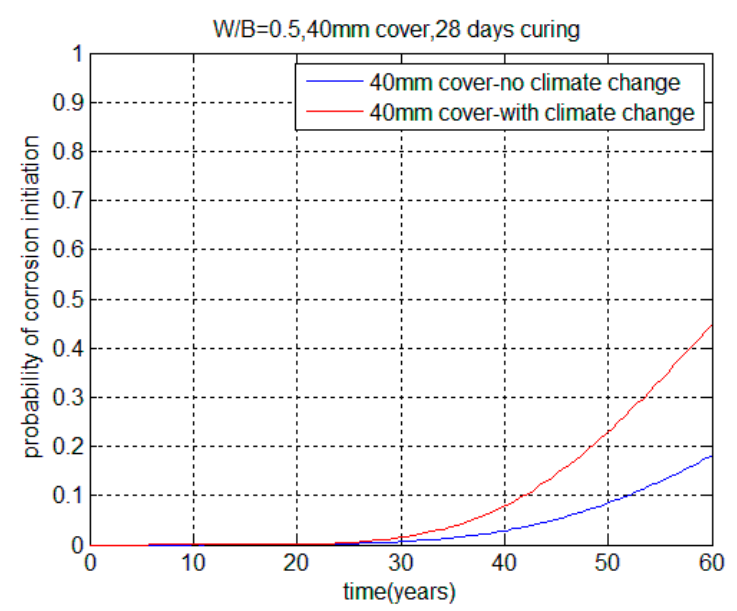

(b)

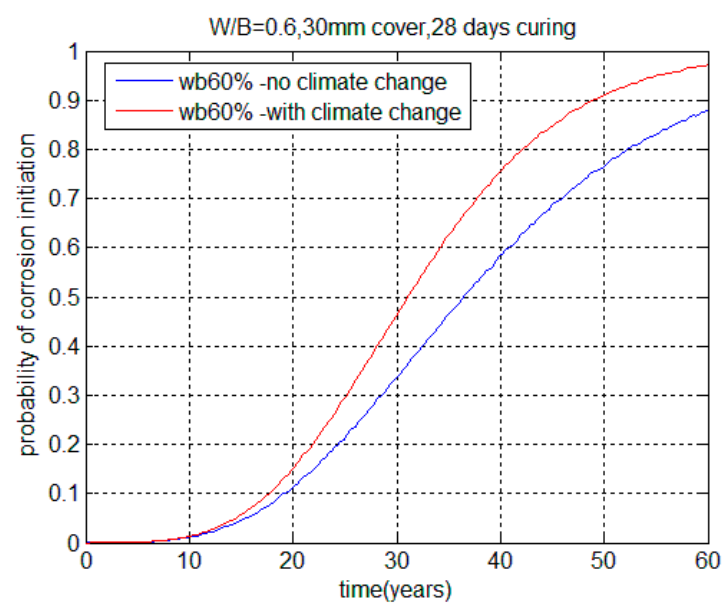

(d)

Figure 6. Probability of corrosion initiation. (a) $W / B=0.5,30 \mathrm{~mm}, 28$ days curing; (b) $W / B=0.5$, $40 \mathrm{~mm}, 28$ days curing; (c) $\mathrm{W} / \mathrm{B}=0.5,30 \mathrm{~mm}$, seven days curing; (d) W/B = 0.6, $30 \mathrm{~mm}, 28$ days curing.

In this study, the service life for the condition of no climate change was defined as the former service life, the service life after considering climate change was defined as modified service life, and relative service life meant the ratio of modified service life to the former service life. The relative service life is shown in Table 4. It appears that greater reductions in the former service life occur for concrete structures with a longer former service life. This is because climate change parameters such as $\mathrm{CO}_{2}$ concentration and environmental temperature monotonously increase with time (shown in Figures 1 and 2). Figure 7 shows the regression relation between relative service life and former service life. With an increase in former service life, relative service life decreases almost linearly.

Table 4. Service life in corrosion initiation stage.

\begin{tabular}{|c|c|c|c|c|c|}
\hline \multirow[b]{2}{*}{ W/B } & \multirow[b]{2}{*}{$\begin{array}{l}\text { Cover Depth } \\
(\mathrm{mm})\end{array}$} & \multirow{2}{*}{$\begin{array}{c}\text { Curing } \\
\text { Periods (Days) }\end{array}$} & \multicolumn{3}{|c|}{ Service Life in Corrosion Initiation Stage (Years) } \\
\hline & & & $\begin{array}{c}\text { No Climate } \\
\text { Change }\end{array}$ & $\begin{array}{l}\text { With Climate } \\
\text { Change }\end{array}$ & Relative Ratio \\
\hline 0.5 & 30 & 28 & 25.06 & 22.38 & 0.89 \\
\hline 0.5 & 40 & 28 & 51.96 & 41.85 & 0.81 \\
\hline 0.5 & 30 & 7 & 18.15 & 16.63 & 0.92 \\
\hline 0.6 & 30 & 28 & 19.36 & 17.61 & 0.91 \\
\hline
\end{tabular}




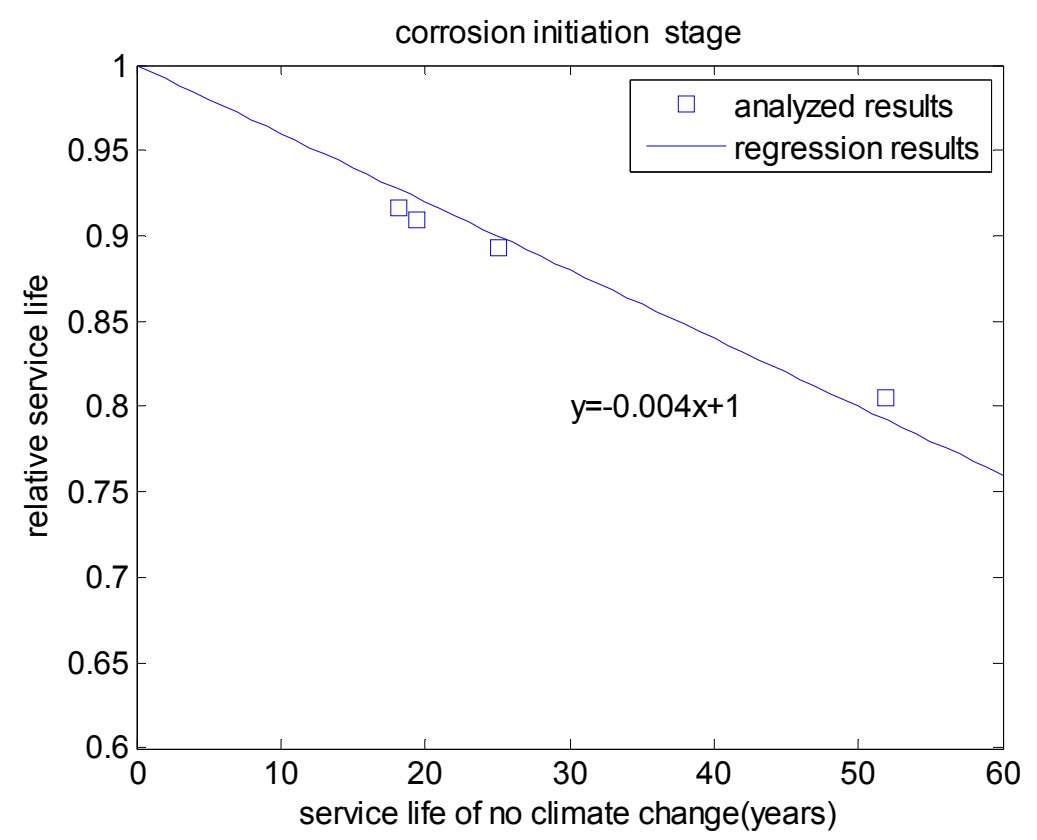

Figure 7. Relative service life in corrosion initiation stage.

\subsection{Service Life in Corrosion Propagation Stage}

In the corrosion propagation stage, the service life of HVFA concrete is determined by using Equation (19). The age dependence of the compressive strength and tensile strength of concrete is evaluated by using the CEB-FIP (European Committee for Concrete and International Federation for Structural Concrete) model code [23]. By using the corrosion propagation model and Monte Carlo method, the probability of corrosion cracking can be calculated. In the stage of corrosion propagation after carbonation, owing to the increase in temperature, rate of corrosion increases, probability of corrosion cracking increases, and service life decreases. As shown in Figure 8, with an increase in the cover depth (comparisons between Figure 8a,b), increasing curing periods (comparisons between Figure $8 \mathrm{a}, \mathrm{c}$ ), and decreasing water-to-binder ratios (comparison between Figure 8a,d), the probability of corrosion cracking decreases. Consequently, the service life of concrete increases. The relative service life is given in Table 5. In analogy with the results in Table 4, higher reductions in the former service life occur for concrete structures with longer former service life. However, in the corrosion propagation stage, the degree of reduction in the former service life is lower than that in the corrosion initiation stage. In the corrosion initiation stage, when the former service life is about 50 years, after considering climate change, the former service life reduces by about $20 \%$. Contrastively, in the corrosion propagation stage, the former service life reduces by about $3.5 \%$. The reason for this difference is that in the corrosion initiation stage, increase in both $\mathrm{CO}_{2}$ concentration and temperature affects service life, while in the corrosion propagation stage, only increase in temperature affects service life. As shown in Figure 9, with increasing the former service life, the relative service life decreases. In this study, a service life of 50 years is used as a representative value of different former service lives. For other values of service life, the relative service life can be calculated by using the regression equations shown in Figures 7 and 9. 


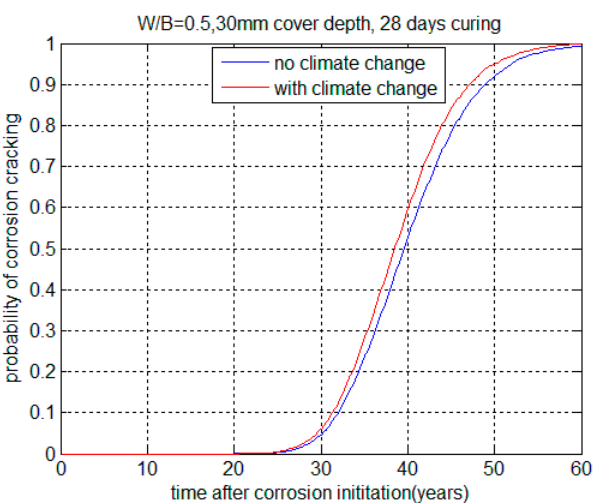

(a)

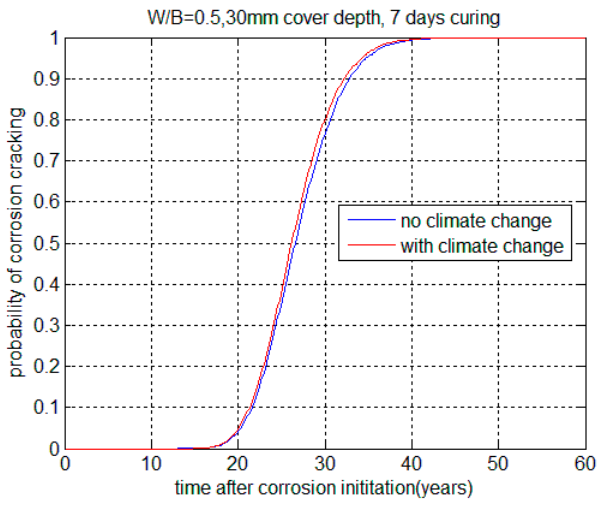

(c)

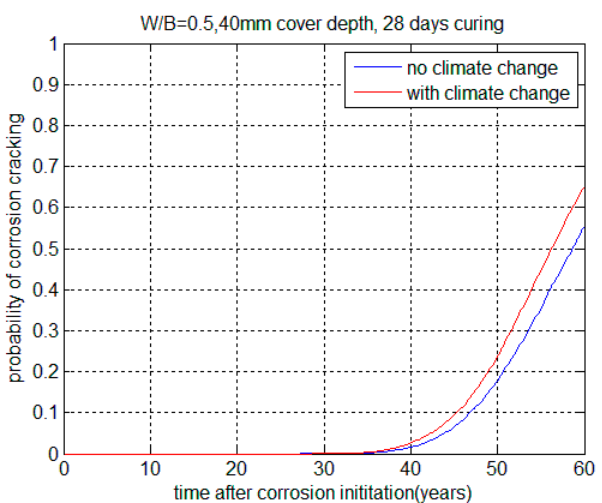

(b)

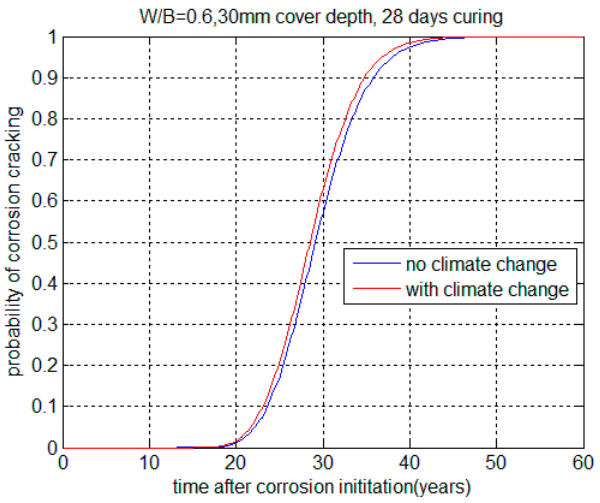

(d)

Figure 8. Probability of corrosion cracking. (a) $W / B=0.5,30 \mathrm{~mm}, 28$ days curing; (b) $W / B=0.5$, $40 \mathrm{~mm}, 28$ days curing; (c) $\mathrm{W} / \mathrm{B}=0.5,30 \mathrm{~mm}$, seven days curing; (d) W/B = 0.6, $30 \mathrm{~mm}, 28$ days curing.

Table 5. Service life in corrosion cracking propagation stage.

\begin{tabular}{|c|c|c|c|c|c|}
\hline \multirow[b]{2}{*}{ W/B } & \multirow{2}{*}{$\begin{array}{l}\text { Cover Depth } \\
(\mathrm{mm})\end{array}$} & \multirow{2}{*}{$\begin{array}{c}\text { Curing } \\
\text { Periods (Days) }\end{array}$} & \multicolumn{3}{|c|}{ Service Life in Corrosion Propagation Stage (Years) } \\
\hline & & & $\begin{array}{l}\text { No Climate } \\
\text { Change }\end{array}$ & $\begin{array}{l}\text { With Climate } \\
\text { Change }\end{array}$ & Relative Ratio \\
\hline 0.5 & 30 & 28 & 32.18 & 31.34 & 0.973 \\
\hline 0.5 & 40 & 28 & 46.66 & 45.19 & 0.968 \\
\hline 0.5 & 30 & 7 & 21.68 & 21.36 & 0.985 \\
\hline 0.6 & 30 & 28 & 23.45 & 23.08 & 0.984 \\
\hline
\end{tabular}

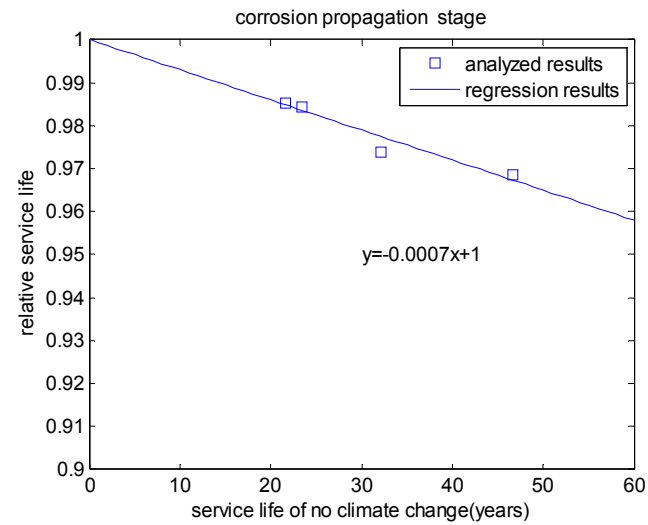

Figure 9. Relative service life in corrosion propagation stage. 


\subsection{Whole Effect of Climate Change on Service Life}

The whole service life of concrete equals the sum of service lives in the corrosion initiation and corrosion propagation stages. By using the model results of service life in the corrosion initiation stage (given in Table 4) and in corrosion propagation stage (given in Table 5), the whole service life was calculated (given in Table 6). As shown in Figure 10, climate change has a significant impact on the service life of durable concrete. For HVFA concrete with a former service life 98.5 years, after considering the effect of climate change, the former service life reduces almost $12 \%$.

Table 6. Whole service life of concrete.

\begin{tabular}{cccccc}
\hline & \multirow{2}{*}{$\begin{array}{c}\text { Cover Depth } \\
(\mathbf{m m})\end{array}$} & $\begin{array}{c}\text { Curing } \\
\text { W/B }\end{array}$ & & \multicolumn{3}{c}{ Service Life (Years) } \\
\cline { 4 - 6 } & 30 & 28 & 57.24 & 53.72 & Nods (Days) \\
\hline 0.5 & 40 & 28 & 98.62 & 87.04 & 0.94 \\
0.5 & 30 & 7 & 39.83 & 37.99 & 0.88 \\
0.5 & 30 & 28 & 42.81 & 40.69 & 0.954 \\
0.6 & & & & With Climate \\
Change & Relative Ratio \\
\hline
\end{tabular}

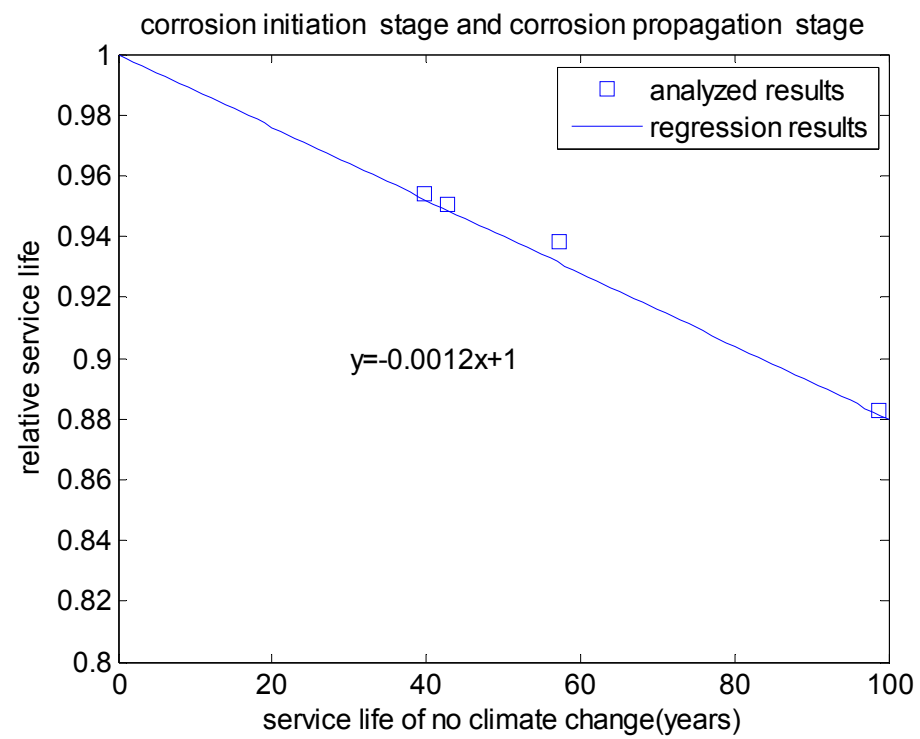

Figure 10. Relative service life of HVFA concrete.

\section{Conclusions}

This study presents a probabilistic approach that predicts the service life of HVFA concrete subjected to carbonation, considering the effects of climate change.

First, in the corrosion initiation stage, by using a blended-cement hydration model, the carbonatable material content and porosity were calculated, and they were used as input parameters for the carbonation-depth prediction model. By using the difference method, the carbonation model considered the effects of climate changes, such as the increase in $\mathrm{CO}_{2}$ concentration and environmental temperature with time, on the service life. The probability of corrosion initiation was calculated by using the Monte Carlo method. In the corrosion initiation stage, for concrete with a former service life of 50 years, after considering the effect of climate change, the former service life was reduced by almost $20 \%$.

Second, in the corrosion propagation stage, the probability of corrosion crack formation was calculated by considering the effect of temperature rise on the rate of corrosion. In the corrosion propagation stage, for concrete with a former service life of 50 years, after considering the effect of 
climate change, the former service life was reduced by almost $3.5 \%$. In the corrosion propagation stage, the degree of reduction in the former service life was lower than that in the corrosion initiation stage because, in the corrosion initiation stage, increases in $\mathrm{CO}_{2}$ concentration, as well as temperature, affect service life, while in the corrosion propagation stage, only temperature increase affected service life.

Third, the whole service life was determined considering the corrosion initiation stage and corrosion propagation stage. Climate change has a significant impact on the service life of durable concrete. With the increasing of former service life, after considering the effect of climate change, the reduction ratio of the former service life increases.

Acknowledgments: This research was supported by the Basic Science Research Program through the National Research Foundation of Korea (NRF), funded by the Ministry of Science, ICT and Future Planning (No. 2015R1A5A1037548).

Author Contributions: Ki-Bong Park made the calculation program; Xiao-Yong Wang analyzed the calculation results. Ki-Bong Park and Xiao-Yong Wang wrote the paper.

Conflicts of Interest: The authors declare no conflict of interest.

\section{References}

1. Pacheco-Torgal, F.; Miraldo, S.; Labrincha, J.A.L.; De Brito, J. An overview on concrete carbonation in the context of eco-efficient construction: Measurement, use of SCM's and/or RCA. Constr. Build. Mater. 2012, 36, 141-150. [CrossRef]

2. Saha, M.; Eckelman, M. Urban scale mapping of concrete degradation from projected climate change. Urban Clim. 2014, 9, 101-114. [CrossRef]

3. Jiang, L.H.; Lin, B.Y.; Cai, Y.B. A model for predicting carbonation of high-volume fly ash concrete. Cem. Concr. Res. 2000, 30, 699-702. [CrossRef]

4. Han, S.H.; Park, W.S.; Yang, E.I. Evaluation of concrete durability due to carbonation in harbor concrete structures. Constr. Build. Mater. 2013, 48, 1045-1049. [CrossRef]

5. Taffese, W.Z.; Sistonen, E.; Puttonen, J. CaPrM: Carbonation prediction model for reinforced concrete using machine learning methods. Constr. Build. Mater. 2015, 100, 70-82. [CrossRef]

6. Marques, P.F.; Costa, A. Service life of RC structures: Carbonation induced corrosion prescriptive vs. performance-based methodologies. Constr. Build. Mater. 2010, 24, 258-265. [CrossRef]

7. Marques, P.F.; Chastre, C.; Nunes, A. Carbonation service life modelling of RC structures for concrete with Portland and blended cements. Cem. Concr. Compos. 2013, 37, 171-184. [CrossRef]

8. Yoon, I.S.; Copuroglu, O.; Park, K.B. Effect of global climatic change on carbonation progress of concrete. Atmos. Environ. 2007, 41, 7274-7285. [CrossRef]

9. Den Heede, P.V.; De Belie, N. A service life based global warming potential for high-volume fly ash concrete exposed to carbonation. Constr. Build. Mater. 2014, 55, 183-193. [CrossRef]

10. den Heede, P.V.; De Belie, N. Environmental impact and life cycle assessment (LCA) of traditional and "green" concretes: Literature review and theoretical calculations. Cem. Concr. Compos. 2012, 34, 431-442. [CrossRef]

11. Talukdar, S.; Banthia, N.; Grace, J.R. Carbonation in concrete infrastructure in the context of global climate change-Part 1: Experimental results and model development. Cem. Concr. Compos. 2012, 34, 924-930. [CrossRef]

12. Talukdar, S.; Banthia, N.; Grace, J.R.; Cohen, S. Carbonation in concrete infrastructure in the context of global climate change: Part 2-Canadian urban simulations. Cem. Concr. Compos. 2012, 34, 931-935. [CrossRef]

13. Talukdar, S.; Banthia, N. Carbonation in concrete infrastructure in the context of global climate change: Development of a service lifespan model. Constr. Build. Mater. 2013, 40, 775-782. [CrossRef]

14. Stewart, M.G.; Wang, X.M.; Nguyen, M.N. Climate change impact and risks of concrete infrastructure deterioration. Eng. Struct. 2011, 33, 1326-1337. [CrossRef]

15. Vu, K.A.T.; Stewart, M.G. Structural reliability of concrete bridges including improved chloride-induced corrosion models. Struct. Saf. 2000, 22, 313-333. [CrossRef]

16. Wang, X.Y.; Lee, H.S. Modeling the hydration of concrete incorporating fly ash or slag. Cem. Concr. Res. 2010, 40, 984-996. [CrossRef] 
17. Papadakis, V.G. Effect of supplementary cementing materials on concrete resistance against carbonation and chloride ingress. Cem. Concr. Res. 2000, 30, 291-299. [CrossRef]

18. Demis, S.; Efstathiou, M.P.; Papadakis, V.G. Computer-aided modeling of concrete service life. Cem. Concr. Compos. 2014, 47, 9-18. [CrossRef]

19. Korea Meteorological Administration. Available online: http://www.kma.go.kr/ (accessed on 1 November 2016).

20. Ann, K.Y.; Pack, S.W.; Hwang, J.P.; Song, H.W.; Kim, S.H. Service life prediction of a concrete bridge structure subjected to carbonation. Constr. Build. Mater. 2010, 24, 1494-1501. [CrossRef]

21. Wei, J.; Meng, H.; Xue, S.G. FEM analysis on the crack process of concrete cover induced by non-uniform corrosion of re-bar. J. Xi'an Univ. Archit. Technol. 2011, 43, 747-754.

22. Chen, D.; Mahadevan, S. Chloride-induced reinforcement corrosion and concrete cracking simulation. Cem. Concr. Compos. 2008, 30, 227-238. [CrossRef]

23. Mehta, P.K.; Monteiro, P.J.M. Concrete, Microstructure, Properties and Materials; McGraw-Hill: New York, NY, USA, 2006.

(C) 2017 by the authors; licensee MDPI, Basel, Switzerland. This article is an open access article distributed under the terms and conditions of the Creative Commons Attribution (CC BY) license (http://creativecommons.org/licenses/by/4.0/). 